

SOME REASONS FOR FAILURE OF FISH PROTECTIVE LEGISLATION AND SOME SUGGESTED REMEDIES

*

By Oregon Milton Dennis

Former State Game Warden of Maryland

$*$

Address before the Fourth International Fishery Congress held at Washington, U. S. A., September 22 to 26, 1908

BULLETIN OF THE BUREAU OF FISHERIES : : VOL. XXVIII, P. 187-192

Document No. 650 : : : : : : : : : : : : : : : : Issued January, 1910 


$$
\left.\operatorname{sit}^{2^{2}} n^{2}\right)^{4}
$$

FEB 41910

in $\mathrm{CH}_{\mathrm{n}}$

$\therefore \vdots \vdots$ 


\title{
SOME REASONS FOR FAILURE OF FISH PROTECTIVE LEGISLATION AND SOME SUGGESTED REMEDIES.
}

\author{
$*$ \\ BY OREGON MILTON DENNIS, \\ Former State Game II arden of Maryland.
}

4

Mr. President, Ladies, And Gentlemen: In speaking on this subject I want it distinctly understood in the beginning that, while my language will appear to be liarsh and my criticism severe with reference to some causes for the failure of the passage of proper and effective fish protective legislation, I am dealing with this subject in generalities, and without particular reference to any person or protective association. I have come to the conclusions which follow after very mature deliberation, and shall deal with this, as I have with every other matter with which I have had to do, in an honest and fearless manner, my sole purpose being to aid in fish protection and to point out some of the reasons why it has failed. A long experience as secretary and counsel of a large protective association and as the state game warden of Maryland, as well as my legislative experience, has, I believe, fully qualified me to express some opinions on the subject-matter of this paper. Of course, this experience has been gained in iny own state, and what I shall say will deal largely with the conditions in that state.

The political division of Maryland through the representation of county members in the legislature places the control of legislation within the power of the counties; notwithstanding the fact that while about one-lialf of the population is centered in Baltimore city the latter has only about one-fourth of the delegates. I mention this because protective influences originate very largely in the city, and the state's chief protective association is there, composed of men who, whether intelligently or not, frame the bills that are presented to the legislature for action. I say intelligently, because while this association includes some of the wealthiest and best of our citizens, its enthusiasm for protection of both game and fish and the bills framed by it are largely based on the selfish reasons of sportsmen, and largely without regard to intelligent conclusions with reference to the rights of the commercial fishermen, whose vote is sufficiently large in tide-water sections of our state to control the electorate. This being 
true, the county members of the legislature, as well as the fishermen themselves, look with suspicion upon any measure presented to the legislature which has for its purpose the protection of fish and game when such measure is presented by city men.

Growing out of this condition (about two years ago) a fishermen's protective association was formed in Maryland for the distinct purpose of fighting the city association, on the ground that the latter was unfair and that its only interest in protection, it was believed, was to secure to the angler a good day's fishing without regard to the commercial fisherman's interest. This condition grew out of a policy of the game protective association of introducing measures abolishing the use of all sorts of nets, or so restricting their use that the commercial fisherman would be put out of business. I am happy to say, however, that during the past year, I believe largely through my own efforts as state game warden, the two associations have united on a number of measures for fish protection, though without specific results.

Unfortunately, the selfish interest of one class and the suspicions of another are largely the reason for the failure of proper fish protective legislation. The angler goes to the legislature with a bill based on his idea of what the law should be, and that idea is usually the prohibition of the use of all sorts of nets which will interfere with his sport; an other class, the commercial fishermen, prepare a bill to protect them in the use of the sort of nets with which they fish, and still another set of fisliermen have a bill to protect them in their method. 'The result is that the legislative committee before whom these bills go is pulled and hauled and besieged and worked upon by the various interests to such an extent that it becones disgusted and pigeonholes all the bills, so that none is passed.

Another reason is that while the state of Maryland spends thousands of dollars for fish culture it persistently refuses to make any appropriation for, or to give the state warden department any material assistance in, the enforcement of such laws as we now have; and while the state navy is charged by law to enforce the laws for fish protection, the character of its boats prevents them from going into shallow waters to do any work even if time permitted to divert the boats from oyster protection to do this.

What I have said above is but the foundation for specific reasons which I shall give for failure of protective legislation, and which in my opinion can be reduced to the following, to wit:

I. Up to this time it has been absolutely impossible to get the tide-water fishermen to agree on any bills, and, in my judgment, even if proper laws were enacted, under the system in our state they would absolutely fail of enforcement.

2. I declare, next to the above reason, that the greatest reason for nonpassage of fish protective bills is the action and influence of the duck gunners 
of Maryland, who, either by purchase or by lease, secure absolute control of water fronts in the tide-water counties for their ducking clubs and slooting grounds. These gentlemen, among the foremost citizens of our state, and largely residents of the city, are jealous of the rights that they claim they have paid for, and in order that they may preserve them are in constant conflict with the resident fishermen, who ply their industry in the waters fronting or adjacent to these shores. Against these men of wealth and influence there is small opportunity to prevail with the legislators when there is a conflict between the rights of the duckers and the fishermen.

There are a number of other reasons which, in my opinion, prevent the passage of proper fish protective laws, but these are sufficient for my purpose.

Now as to the remedy. I sliall offer but one, but I think it will be sufficiently radical to bring down on my head all the knocks that I can stand up under. You will remember that I made this suggestion at the last annual meeting of the American Fisheries Society:

Admitting the necessity for protection of young fish after they have been placed in the waters by the States and the. United States, the question that confronts us is, how? I believe that, if it comes within the constitutional powers of the Government, Congress should pass proper interstate laws for the protection of fish.

Thousands of dollars are being spent, practically wasted, for fish propagation in Maryland. The state has persistently neglected to provide for protection. Not until after fifty years of constant agitation and the practical extermination, commercially, of the oyster, has Maryland been awakened (and that but two years ago) to the fact that the oyster in Maryland must be protected or exterminated. If it has taken this long to awaken to the serious condition of the oyster, how long will it take to recognize the necessity for the protection of the fish, and thus save to the people of our own state and other communities and from extermination one of the greatest natural food products of the world?

Mr. Bryan, at the conference of the governors of the states held in May last in Washington, had this to say with reference to the protection of the great natural resources of the country-that he regarded "the development of water transportation as essentially a national project, because the water courses run by and through many states." In my judgment it is just as important for the National Government to protect the natural industry which has its life and being as a food product in and under the waters of this country as it is to enlarge and protect the waterways for the carrying away from and bringing to us the great commerce of the world. I believe it more important, because the products of the water provided food to man long before he thought of the creation of great fortunes by the use of water courses for commercial purposes. 
I am a state's rights man, and an jealous of any action of the National Government whicl would deprive the state of a single right. But when I consider that the great bodies of water which protuce natural food run through and by different states; when I consider that petty political influences, jealousies, and other equally silly reasons prevent a state from protecting from extermination a natural food product, I am convinced that the only solution of this question is in rational control of the fish by the Federal Government. I hope this congress will put itself on record to that end, for I believe that not until this is done and the Federal Government legislates for fish protection and supplies its powerful backing to the enforcement of such laws will the question of fish protection be solved. 

